\title{
Human rights through the lens of disability
}

\section{Kjersti Skarstad}

Department of Political Science, University of Oslo. E-mail: kjersti.skarstad@ stv.uio.no

\begin{abstract}
Notions discriminatory to persons with disabilities commonly underpin political theories of rights. While persons without disabilities are considered "normal" and independent, persons with disabilities are commonly seen as "deviant" and dependent. Persons with intellectual disabilities are also seen as lacking the autonomy required to have human rights. Acknowledging the equal human rights of all human beings, the United Nations Convention on the Rights of Persons with Disabilities (CRPD) refutes such notions. Drawing upon relational theory, this Article provides a theoretical basis to some of the novel features of the CRPD. In contrast to many dominant theories of rights, the author argues that 1) disability constitutes a natural part of human diversity, 2) human beings are interdependent, 3) rights are achieved through supportive relations, and 4) human rights are ideals that inform how we should treat each other. The Article shows that a human rights theory fully inclusive of persons with intellectual disabilities also strengthens the human rights of others.
\end{abstract}




\section{INTRODUCTION}

Political theories rarely mention the human rights of persons with disabilities, and when they do, they commonly argue that not all persons with disabilities are entitled to full human rights protection. In addition, they tend to portray persons with disabilities as categorically different from others. ${ }^{1}$ In contrast to "normal" persons who are seen as independent, persons with disabilities (and persons with intellectual disabilities in particular) tend to be seen as deviant and dependent. Persons with intellectual disabilities are seen as lacking the autonomy required to have human rights. Enacted in 2006, the United Nations Convention on the Rights of Persons with Disabilities (CRPD) became the first international human rights convention to explicitly refute such notions and to firmly acknowledge that human rights are not subject to disability-based restrictions.

Existing academic literature on the CRPD explains well how the CRPD develops concepts of human rights law (for example, non-discrimination), and how it is underpinned by the idea of persons with disabilities as active agents rather than medical objects or objects of pity. ${ }^{2}$ Recent legal literature has also pointed out that human rights law has developed from individualistic to more relational conceptions of selfhood, with the CRPD being the clearest example of this change. ${ }^{3}$

While the literature on the CRPD advances equality-based conceptions of disability and rights, it does not directly address the discriminatory notions of disability found in political theories of rights, and hence do not sufficiently explain how we can perceive of human rights as not having any disability based-restrictions. In particular, theoretical literature on how persons with intellectual disabilities can have the same human rights as their non-

\footnotetext{
${ }^{1}$ Martha Nussbaum, Frontiers of Justice: Nationality, Disability, Species Membership (Harvard University Press 2006); Eva Feder Kittay and Licia Carlson (eds), Cognitive Disability and its Challenge to Moral Philosophy (John Wiley \& Sons 2010); Barbara Arneil, 'Disability, Self Image, and Modern Political Theory' (2009) 37 Political theory 218.

${ }^{2}$ Rosemary Kayess and Phillip French, 'Out of Darkness into Light? Introducing the Convention on the Rights of Persons with Disabilities’ (2008) 8 Human Rights Law Review 1; Raymond Lang and others, 'Implementing the United Nations Convention on the Rights of Persons with Disabilities: Principles, Implications, Practice and Limitations' (2011) 5 ALTER - European Journal of Disability Research / Revue Européenne de Recherche sur le Handicap 206; Frédéric Mégret, 'The Disabilities Convention: Human Rights of Persons with Disabilities or Disability Rights?' (2008) 30 Human Rights Quarterly 494; Frédéric Mégret, 'The Disabilities Convention: Towards a Holistic Concept of Rights' (2008) 12 The International Journal of Human Rights 261; Michael Ashley Stein, 'Disability Human Rights' (2007) 95 California Law Review 75.

${ }^{3}$ Danai Angeli, 'Positive Obligations in Human Rights Law: the Disabilities Paradigm Shift' (Dissertation, European University Institute, 2015); Arlene S Kanter, The Development of Disability Rights under International Law: from Charity to Human Rights (Routledge 2014).
} 
disabled peers is insufficient. ${ }^{4}$ Human rights practices are informed by certain understandings, ${ }^{5}$ and for the human rights of persons with disabilities to become a reality, it is thus important that the novel assertions of the CRPD are understood and underpinned with strong theoretical arguments. ${ }^{6}$ How can established understandings of human rights be revised so that they fully include all persons with disabilities?

This Article contributes to this question by focusing particularly on intellectual disability and by addressing two assertions often claimed in political theory but opposed by the CRPD: that persons with disabilities are abnormal, and that they lack the autonomy required for human rights. As such the Article provides a bridge between political (human rights) theory and human rights law. Relational theory - theory having as a core premise that the human being is socially situated and formed - is drawn upon and developed to make four interrelated theoretical points that explain the CRPD's statements on disability and equal human rights protection:

1) Disability is a natural part of human diversity, and all humans can acquire a disability. If disability is seen as vulnerability and a stronger dependency on others due to cognitive or physical capacities that differ from those of the "average person", then all persons will experience disability during their life, particularly in childhood and in old age. Like race, sex, or sexual orientation, disability is just one of many characteristics of a person. A disability does not predefine an individual, and its consequences vary according to social context.

2) Human beings are interdependent. Our social bonds and networks constitute our own being, and we all depend on others to develop and thrive. Persons with intellectual disabilities are no different in this sense and may, as others, contribute positively to society, for example by increasing the knowledge base on human needs and possibilities and by potentially strengthening our moral connections with each other.

\footnotetext{
${ }^{4}$ Eva Feder Kittay and Licia Carlson, Cognitive Disability and its Challenge to Moral Philosophy (John Wiley \& Sons 2010).

${ }^{5}$ Charles Taylor, Philosophical Papers: Volume 2, Philosophy and the Human Sciences (Cambridge University Press 1985).

${ }^{6}$ See Taylor (n 5) for how theory influence the way we act. See Kjersti Skarstad 'Realizing the Human Rights of Persons with Disabilities. From Political Ideals to Political Practices' (Dissertation, University of Oslo, 2017) for how this applies to human rights specifically. See for example Douglas C Bayton, 'Disabilitiy and the Justification of Inequality in American History' in J Lennard Davis (ed), The Disability Studies Reader (4th edn, Routledge 2013); Michael Ashley Stein, 'Same Struggle, Different Difference: ADA Accommodations as Antidiscrimination' (2004) 153 University of Pennsylvania Law Review 579; János Fiala-Butora, 'Disabling Torture: the Obligation to Investigate Ill-Treatment of Persons with Disabilities' (2013) 45 Columbia Human Rights Law Review 214; Michael Oliver and Colin Barnes, The New Politics of Disablement (Palgrave Macmillan 2012) for how discriminatory notions similar to those made in political theory are shared by many decision makers and law enforcers.
} 
3) Rights are achieved through supportive relations. Embeddedness in just social relations (relations observing each individual's human rights) is, for example, crucial to the realisation of individuals' self-determination (autonomy). Inclusion in social networks strengthens individuals' capabilities to make good choices. Everyone depends on others for advice and information in decision-making processes, but the necessary assistance to persons with intellectual disabilities may differ in extent and implementation. Creating just social relations is in itself an important purpose of human rights.

4) Human rights are ideals that inform how we should treat each other. An understanding of human rights that focuses on equal rights instead of equal capabilities includes all human beings equally, despite our individual differences. Indeed, human rights conventions build upon (and thus need to be understood as observing) the fundamental moral premise that all human beings have human rights. All individuals should be treated according to the same moral standards (human rights) that help individuals develop and thrive. However, because different human beings have different abilities and challenges, the fulfillment of equal rights may require different approaches for different groups.

The Article starts with a brief presentation of exclusionary notions of persons with disabilities found in political theories of rights. The following Section will discuss how the CRPD opposes such notions and how the CRPD reflects insights from relational theory. The four theoretical points explaining the CRPD's statements on disability and equal human rights are presented in the last (and main) part of the Article. This part also describes the types of conceptions (or misconceptions) that lead to the exclusion of persons with disabilities, and explains why seeing human rights through the lens of intellectual disability offers stronger human rights protection for all individuals.

\section{EXCLUSIONARY NOTIONS OF PERSONS WITH DISABILITIES}

In much of Western political theory, persons with disabilities have been portrayed in limiting, depreciating and discriminatory ways. ${ }^{7}$ Prominent theorists have excluded persons with disabilities from general social justice-based accounts by seeing the injustices facing persons

\footnotetext{
7 Arneil (n 1); David Wasserman and others, 'Disability and Justice' (2013) <https://plato.stanford.edu/entries/disability-justice/ 2013> accessed 15 March 2017.
} 
with disabilities as a natural result of their medical limitations. ${ }^{8}$ Although there has been a move towards a social justice-based understanding of disability in recent years, disagreement exist as to whether persons with the most severe intellectual disabilities even qualify as subjects of justice. ${ }^{9}$ Some renowned political theorists have gone as far as explicitly depriving some persons with disabilities of their very humanity. Singer and Kuhse, ${ }^{10}$ for example, state that 'some infants with severe disabilities should be killed', and McMahan argues that it is less bad to kill humans who are severely intellectually disabled than to kill one of "us."11

Human rights theory has not sufficiently refuted discriminatory theories of persons with disabilities. Although the core of human rights is that all human beings have inherent dignity, human rights theorists have only rarely mentioned explicitly the rights of persons with disabilities, and when they have been mentioned, they have tended to provide arguments that strip persons with disabilities of equal rights. For example, Griffin argues that children and the severely disabled do not have human rights because they lack normative agency. ${ }^{12}$ Nickel explicitly defines human rights as rights that are universal in the sense of belonging to all human beings. ${ }^{13}$ Yet, he also claims that human beings who lack rationality and agency do not have all human rights, and points to persons with intellectual disabilities as an example. According to Nickel, 'the rights of people who are very young, severely retarded [sic], comatose, or senile are justifiably limited [...] it would be implausible to argue that they have rights to vote, run for political office, or travel freely on their own'. ${ }^{14}$

Griffin's and Nickel's strong focus on agency and rationality as justifying human rights, and the concurring notion of some persons with disabilities as not fulfilling these conditions, is symptomatic of what in this Article is termed the individualistic liberal tradition (a category within the broad and diverse liberal school). This tradition conceptualises human beings as essentially a priori independent and autonomous, and has strongly influenced Western political thought and the human rights movement. ${ }^{15}$ Article 1 of the Universal Declaration of Human Rights, for example, can be read as reflecting such a notion of human rights because it states

\footnotetext{
${ }^{8}$ See for example Wasserman and others (n 7) for how theorists such as Dworkin and Daniels perceive of disability through what has been termed the medical model of disability. For further explanation on how the medical model of disability negates the human rights of persons with disabilities see Stein (n 2).

${ }^{9}$ Wasserman and others (n 7).

${ }^{10}$ Helga Kuhse and Peter Singer, Should the Baby Live?: the Problem of Handicapped Infants (Oxford University Press 1985).

${ }^{11}$ Jeff McMahan, The Ethics of Killing: Problems at the Margins of Life (Oxford University Press 2002).

12 James Griffin, On Human Rights (Oxford University Press 2008).

${ }^{13}$ James W Nickel, Making Sense of Human Rights (2nd edn, Blackwell Publishing 2007).

14 ibid.

${ }^{15}$ Arneil (n 1); Mégret (n 2) 'The Disabilities Convention: Human Rights of Persons with Disabilities or Disability Rights?'.
} 
that 'All human beings are born free and equal in dignity and rights. They are endowed with reason and conscience [...]' (emphasis added).

The interlinking of autonomy, rationality and human rights dates back to the birth of the human rights movement with Enlightenment thinkers such as Locke and Mill, and is clearly reflected in the many versions of social contract theory, which still represents the most common way of theorising human rights. ${ }^{16}$ Social contract theories imagine a state preceding the organisation of society, where the starting point is the needs, rights and wishes of equally situated individuals. Individuals are equally situated because they have the same capacity for reasoning and making autonomous decisions - qualities that give rise to equal rights and economic and social cooperation. ${ }^{17}$

A core problem with such theories is that persons with disabilities are commonly not seen as equally situated and cooperating members of society. ${ }^{18}$ For example, Rawls leaves 'aside permanent physical disabilities and mental disorders so severe as to prevent persons from being normal and fully cooperating members of society in the usual sense'. ${ }^{19}$ As thoroughly explained by Nussbaum and by Silvers and Francis, in Rawls' theory of justice some persons with disabilities are regarded as second-class citizens or worse-as noncitizens. ${ }^{20}$ A few scholars have sought to rehabilitate social contract theories so that they fully include the human rights of all persons with disabilities, ${ }^{21}$ and others have rejected the possibility that these types of theories appropriately account for disability. ${ }^{22}$

Individualistic liberal theories are not the only branch of political theory containing devaluing notions of persons with disabilities. Taylor, ${ }^{23}$ usually regarded as a communitarian, argues forcefully that all human beings have human rights. According to him, human rights protect human capacities that demand our respect. Although some persons with disabilities lack some of these capacities, they still have human rights, but only because 'the status of being a

\footnotetext{
${ }^{16}$ Mégret (n 2) 'The Disabilities Convention: Towards a Holistic Concept of Rights'; Nussbaum (n 1); Carlos A Ball, 'Looking for Theory in All the Right Places: Feminist and Communitarian Elements of Disability Discrimination Law’ (2005) 66 Ohio State Law Journal 105.

${ }^{17}$ Anita Silvers and Leslie Pickering Francis, 'Thinking about the Good: Reconfiguring Liberal Metaphysics (or not) for People with Cognitive Disabilities' (2009) 40 Metaphilosophy 475; Ball (n 16); Gerald Gaus, Shane D Courtland and David Schmidtz, 'Liberalism' (2015) Stanford Encyclopedia of Philosophy

<http://plato.stanford.edu/archives/spr2015/entries/liberalism/> accessed 20 May 2016.

${ }^{18}$ Silvers and Francis (n 17); Arneil (n 1); Nussbaum (n 1); Wasserman and others (n 7).

${ }^{19}$ John Rawls, A Theory of Justice (Harvard University Press 1999) 234.

${ }^{20}$ Nussbaum (n 1); Silvers and Francis (n 17).

${ }^{21}$ Anita Silvers and Leslie Pickering Francis, 'Justice through Trust: Disability and the 'Outlier Problem' in Social Contract Theory' (2005) 116 Ethics 40; Sophia Isako Wong, 'The Moral Personhood of Individuals Labeled 'Mentally Retarded': a Rawlsian Response to Nussbaum' (2007) 33 Social Theory and Practice 579. ${ }^{22}$ Nussbaum (n 1).

23 Taylor (n 5).
} 
creature defined by its potential for these capacities cannot be lost'.${ }^{24}$ Hence, as Arneil puts it, to Taylor some persons with disabilities are "potential" persons only, and severe disability is portrayed as a tragedy. ${ }^{25}$

In line with Taylor, Nussbaum also argues for the equal rights of persons with disabilities. ${ }^{26}$ Nevertheless, as several authors have pointed out, she does not manage to include all human beings in her theory of justice. ${ }^{27}$ Having defined ten functional human abilities (including rational thought, emotions, reasoning and holding property), she claims that 'a life without any possibility at all of exercising these at any level is not fully a human life'. ${ }^{28}$

In contrast to the dominant individualistic liberal theories of rights, both Taylor and Nussbaum have as a core theoretical premise that the human being is socially situated and formed. Theories sharing this premise are in this Article termed relational. Although relation theory also lacks sufficient explanation as to how we can perceive of all persons with disabilities as having equal human rights to their non-disabled peers, relational theories have proved particularly fertile in establishing the equal rights of persons with disabilities. Relational theories explain how individuals are restrained and supported by the socially constructed environment and become who they are through interactions with others. Importantly, although noticing that individual capabilities vary, relational theories argue that rationality and autonomy are achieved through support and assistance from others. ${ }^{29}$

Relational theories thus criticise the assumption of the "pre-society" independent rational being pictured by individualistic liberal theories and use this critique to show that vulnerability and dependency — characteristics usually attached to persons with disabilitiesare in fact central features of the human experience. ${ }^{30}$ Arneil, for example, claims that disability is a 'dimension of human diversity across space and time rather than a tragedy, deficit, or abnormality. ${ }^{31}$ Discriminatory social structures (or oppressive relations), prejudice, and the

\footnotetext{
24 Taylor (n 5) 194.

${ }^{25}$ Arneil (n 1).

${ }^{26}$ Nussbaum (n 1).

${ }^{27}$ Arneil Silvers and Francis (n 17); Stein (n 2).

${ }^{28}$ Nussbaum (n 1) 180. Nussbaum (n 1) 96-7, 192-3 exemplifies by concluding that while Arthur (who has Asperger's) and Jamie (who has Down syndrome) may be able to attain the capabilities that are 'humanly central,' Sesha (who has cerebral palsy and a severe intellectual disability) cannot attain all such capabilities. Nussbaum states that ' $[\mathrm{t}]$ his is an unhappy state of affairs $[. .$.$] the only way that Sesha can ever flourish is as a$ human being'.

${ }^{29}$ Catriona Mackenzie and Natalie Stoljar (eds), Relational Autonomy: Feminist Perspectives on Automony, Agency, and the Social Self (Oxford University Press 2000); Janet E Lord and Michael Ashley Stein, 'Contingent Participation and Coercive Care' in Bernadette McSherry and Ian Frecelton (eds), Coercive Care: Rights, Law and Policy (Routledge 2013).

${ }^{30}$ Ball (n 16).

${ }^{31}$ Arneil (n 1) 237.
} 
lack of support and accommodation explain why persons with disabilities are disadvantaged. As we shall see in the next Section, the CRPD reflects insights from relational theory.

\section{THE CALLENGE AND NOVELTY OF THE CRPD}

The CRPD is the first international human rights convention unambiguously acknowledging that human rights are not subject to disability-based restrictions. ${ }^{32}$ Article 2 sets out that 'Discrimination on the basis of disability means any distinction, exclusion or restriction on the basis of disability which has the purpose or effect of impairing or nullifying the recognition, enjoyment or exercise, on an equal basis with others, of all human rights [...]' The CRPD explicitly states 35 times that persons with disabilities enjoy human rights on an "equal basis" with others. The CRPD covers all human rights, including civil and political rights (for example, liberty, freedom of movement, freedom of expression and privacy), and economic and social rights, (for example, education, health and work), and explains how to achieve these rights for persons with disabilities. ${ }^{33}$

Article 1 of the CRPD states that '[p]ersons with disabilities include those who have long-term physical, mental, intellectual or sensory impairments which in interaction with various barriers may hinder their full and effective participation in society on an equal basis with others' (emphasis added). The CRPD thus conceptualises rather than strictly defines disability: as society is constantly evolving, so too are disabling barriers and what is considered a disability. The focus is not on individual impairments but on how society can accommodate and include all individuals. ${ }^{34}$

\footnotetext{
${ }^{32}$ Prior to the adoption of the CRPD, disability-based human rights were relegated to 'other status' under the International Covenant on Civil and Political Rights and the International Covenant on Economic Social and Cultural rights, see Kjersti Skarstad and Michael Stein, 'Mainstreaming Disability in the United Nations Treaty Bodies' Journal of Human Rights <http://www.tandfonline.com/doi/full/10.1080/14754835.2017.1286238> accessed 27 January 2017. Although persons with disabilities could have been protected by these Covenants, in practice, recognition of the equal rights of persons with disabilities appeared only rarely in the work of the UN human rights system until the early 2000s, see Quinn G, Degener T and Bruce A, 'Human Rights and Disability: the Current Use and Future Potential of United Nations Human Rights Instruments in the Context of Disability' (United Nations Publications 2002). To illustrate, only four disability-related complaints were declared admissible by the UN human rights treaty bodies from 1993-2002, and only 7\% of the Human Rights Committee's Concluding Observations during 1993-2002 mention the human rights of persons with disabilities (ibid).

${ }^{33}$ For example, to realise the right to education (Art 24), States Parties shall inter alia ensure that education is 'delivered in the most appropriate languages and modes and means of communication for the individual.'

${ }^{34}$ Indeed, the description of disability is not included under the article on definitions, but under the article expressing the purpose of the Convention.
} 
The CRPD is the first UN human rights convention to include a set of general principles that guide the interpretation of all its Articles. ${ }^{35}$ One of these principles is "[r]espect for difference and acceptance of persons with disabilities as a part of human diversity and humanity' (Article 3(d)). Hence, in contrast to much of political theory, disabilities are not perceived as deviations or aberrations, and persons with disabilities are not described in negative terms. In fact, Article 8 (and preamble para. m) requires States Parties to recognise and promote positive contributions to society by persons with disabilities.

Another general principle is ' $[\mathrm{r}]$ espect for individual autonomy including the freedom to make one's own choices' (Article 3a). Unlike much of political theory, the CRPD thus sees all individuals as having autonomy. It is the first convention to mention autonomy explicitly, and it does so four times. Article 12 declares that persons with disabilities not only have the right to be recognised as persons under the law, but also have the right to be legal actors, which basically means that they have the same right as others to make their own decisions. In the context of Article 12, non-discrimination entails that the (presumed) decision-making skills of a person with a disability can never justify restrictions on that individual's right to make decisions on an equal basis with non-disabled persons. ${ }^{36}$

The CRPD not only challenges common perceptions of persons with disability, it also presents a new perspective on human rights. Reflecting insights from relational theory, it focuses extensively on social relations and sees such relations as a way of fulfilling individual rights. 'Full and effective participation and inclusion in society' is a principle of the CRPD (Article 3c). The right to participation represents a broad demand, directed to all aspects of society, and is as such a novel feature of human rights conventions. ${ }^{37}$ Indeed, the CRPD is the first international human rights convention to state that there is a distinct human right to be included in the community. ${ }^{38}$ According to Article 19, States Parties are to 'take effective and appropriate measures to facilitate full enjoyment by persons with disabilities of this right and their full inclusion and participation in the community'.

The understanding of social barriers as impeding equality explains why the CRPD puts heavy emphasis on the need for wide-ranging changes in all aspects of society, including at the administrative, legislative, political, personal, private, and family levels. On this point it

\footnotetext{
${ }^{35}$ Janet E Lord and Michael Ashley Stein, 'Social Rights and the Relational Value of the Rights to Participate in Sport, Recreation, and Play' (2009) 27 Boston University International Law Journal 249.

${ }^{36}$ UN Committee on the Rights of Persons with Disabilities, 'General Comment No 1' (2014) UN Doc CRPD/C/GC/1; Eilionoir Flynn and Anna Arstein-Kerslake, 'Legislating Personhood: Realising the Right to Support in Exercising Legal Capacity' (2014) 10 International Journal of Law in Context 81.

${ }^{37}$ Mégret (n 2), 'The Disabilities Convention: Towards a Holistic Concept of Rights'.

${ }^{38}$ ibid.
} 
goes further than any other human rights convention. ${ }^{39}$ For example, although both the Convention on the Elimination of All Forms of Racial Discrimination (CERD) and the Convention on the Elimination of all Forms of Discrimination Against Women (CEDAW) require States Parties to change prevailing social attitudes, the CRPD also requires States Parties to foster respect for persons with disabilities in all levels of the education system. ${ }^{40}$ The CRPD builds on the definition of discrimination found in CERD and CEDAW, but widens it by adding the lack of reasonable accommodation (the necessary and appropriate modifications and adjustments not imposing a disproportionate or undue burden) as discrimination.

The preamble (para. w) states that 'the individual, having duties to other individuals and to the community to which he or she belongs, is under a responsibility to strive for the promotion and observance of the rights recognised in the International Bill of Human Rights'. The two Covenants have similar formulations, but such recognition is not present in any of the ensuing conventions. ${ }^{41}$ Because discrimination is defined as 'any distinction, exclusion or restriction [of rights] on the basis of disability' (Article 2), persons who have a relation to a person with disability, and experience discrimination because of this, are also protected by the Convention (see also preamble paras. h, x, and Article 5(2)).

\section{RETHINKING DISABILITY AND HUMAN RIGHTS}

The CRPD's account of persons with disabilities and human rights contrasts with the ideas found in mainstream political theory. In particular, the statements on disabilities as natural human variation, on persons with disabilities as positively contributing to society, on autonomy and the right to self-determination as inherent to all human beings, and on social relations as the way to fulfill individual rights are controversial and puzzling, at least in the context of intellectual disability. The remaining part of the Article gives a theoretical basis for these statements. Given the CRPD's strong focus on social relations, drawing upon relational theory is a good place to start. However, and as noted above, relational theory is insufficient in explaining how persons with (severe) intellectual disabilities can have human rights equal to those of persons without intellectual disabilities. Relational theory is thus not only drawn

\footnotetext{
${ }^{39}$ Mégret (n 2), 'The Disabilities Convention: Human Rights of Persons with Disabilities or Disability Rights?' 268.

40 ibid.

${ }^{41}$ Art 29 of the Universal Declaration of Human Rights, however, states '[e]veryone has duties to the community in which alone the free and full development of his personality is possible.'
} 
upon, but also developed. While the overarching focus of Subsections 4.1 and 4.2 is on how disability is a normal part of humanity, Subsections 4.3 and 4.4 focus more specifically on the concept of equal human rights for all human beings.

\subsection{DISABILITY IS A NATURAL PART OF HUMAN DIVERSITY}

Much of political theory deprecates disability by describing persons with disabilities as categorically different from others. This view results when the disability is perceived as the defining element of a person. ${ }^{42}$ However, the CRPD describes disability as a natural part of human diversity (Article 3(d)), and emphasises the individuality of all persons with disabilities (such as Article 3(a)).

Anyone can become disabled at any time. In the United States, illnesses like cancer, heart attack and diabetes are the main causes of long-term disabilities. ${ }^{43}$ Depression is the leading cause of disability worldwide, and often leads the affected person to function poorly at school or at work. $^{44}$ Disability prevalence increases with age, and the changing demographics of societies with more people living to an old age will thus increase the number of persons living with a disability. ${ }^{45}$ It is currently estimated that 1 billion people (15 percent of the world population) have some form of disability. ${ }^{46}$ If disability is seen as vulnerability and dependency that are due to the cognitive or physical differences of the person with disabilities in relation to the "average person," then all of us will experience disability in some sense throughout our lives, particularly through periods of illness, when we are very young, and in old age. ${ }^{47}$ Disability is thus a part of humanity that has previously not been sufficiently addressed by human rights law and theory. ${ }^{48}$

Some are born with a severe disability or acquire a disability considered as "atypical" for a certain age later in life; others will only experience disability in the way that all people experience an increased vulnerability and dependency on others when they become old or ill. In any event, differences in physical and intellectual abilities are differences of degree and not

\footnotetext{
42 Oliver and Barnes (n 6); Skarstad and Stein (n 32); Stein (n 2).

${ }^{43}$ Council for Disability Awareness, 'What Are the Most Common Causes of Disability?' (2017)

<http://www.disabilitycanhappen.org/chances_disability/causes.asp> accessed 2 February 2017.

${ }^{44}$ World Health Organization, 'Depression' (2017) <http://www.who.int/mediacentre/factsheets/fs369/en/> accessed 27 March 2017.

${ }^{45}$ World Health Organization and World Bank, 'World Report on Disability' (2011).

46 ibid.

${ }^{47}$ Jan Tøssebro, 'Introduction to the Special Issue: Understanding Disability' (2009) 2 Scandinavian Journal of Disability Research 3; Martha Albertson Fineman, 'The Vulnerable Subject: Anchoring Equality in the Human Condition' (2008) 20 Yale Journal of Law \& Feminism 8.

${ }^{48}$ Angeli (n 3).
} 
of kind. Like sex and skin color, they reflect human variation. ${ }^{49}$ All individuals differ in their skills and abilities, and are unable to do certain things. Disability, sex, race, and sexual orientation are just some of many characteristics of a person. Many political thinkers focus exclusively on persons' abilities for contemplation and rationality, and by doing so they distinguish persons with intellectual disabilities from others. ${ }^{50}$ Consequently, they ignore other important qualities that particularly people with little philosophical interest may find equally valuable - like the ability for empathy, joy, love and emotional intelligence. Kittay states:

[w] hen philosophers hold that contemplation is the highest human endeavor or that logical inquiry is the crown jewel of the human mind, they either fail to perceive a major source of that value - namely, that of a philosophical temperament - or fall prey to a hubris, which takes what philosophers hold dear to be what all should hold equally dear. Such projection is disrespectful of the lives of others, or of other conceptions of the good, and is contrary to any liberal principles that maintain the plurality of goods. ${ }^{51}$

What is considered a disability, and the challenges an individual faces vary significantly across time and space. ${ }^{52}$ The CRPD acknowledges this by defining disability as occurring when impairments interact with various barriers. ${ }^{53}$ Dyslexia did not occur until reading and writing became important skills, and many persons with bad eyesight would have been considered disabled if they had been living in a society without access to visual aids.

Hence, the identification of an impairment and its effect on the individual's possibilities and life quality vary according to the social circumstances and characteristics of the individual concerned. This is necessarily true for all persons with disabilities. For example, in some societies, newborns with severe or visible intellectual disabilities are killed; in others,

\footnotetext{
${ }^{49}$ See Michael A Stein and Michael E Waterstone, 'Disability, Disparate Impact, and Class Actions' (2006) 56 Duke Law Journal 861 on how the common experience of social exclusion and stigma binds individuals with diverse disabilities together in real life, and how this is parallel to race and sex-based stigma and exclusion.

${ }^{50}$ Eva Feder Kittay, 'Ideal Theory Bioethics and the Exclusion of People with Severe Cognitive Disabilities' in Hilde Lindeman, Marian Verkerk and Margaret Walker Urban (eds), Naturalized Bioethics (Cambridge University Press 2008).

51 ibid.

${ }^{52}$ Lennard J Davis (ed), The Disability Studies Reader (4th edn, Routledge 2013); Oliver and Barnes (n 9).

${ }^{53}$ Disabling barriers can be both social and environmental. The CRPD focuses on the social barriers that impede persons with disabilities from living in societies where their human rights are fulfilled. UN Enable, 'Frequently Asked Questions' (2007) <http://www.un.org/esa/socdev/enable/faqs.htm> accessed 11 May 2017.
} 
persons with intellectual disabilities are locked up in institutions; and in yet others, they receive opportunities and interact with other people in society. ${ }^{54}$

A disability does not pre-define an individual, and disability is not the only defining characteristic of a person. Steven Hawking, a theoretical physicist and cosmologist with a disease that has inter alia gradually paralysed him, is an example of someone who is highly disabled in many ways. Yet he is not disabled in other ways, thanks to modern technology such as speech-generating devices and other accommodations. Hawking is an extraordinary person who illustrates an ordinary point: what you can do and who you become depend to a large degree on your circumstances and the society you live in. Dependency on support, from technical equipment via social institutions (such as schools and workplaces) to supportive personal relations (such as family and friends), necessarily applies to all of us-not only to persons with disabilities.

\subsection{HUMAN BEINGS ARE INTERDEPENDENT}

Individualistic liberal theories of rights emphasise individuals' independence - sometimes to the degree that an individual's situation is understood in isolation from the social context in which the individual lives. The CRPD sees our (dis)abilities as contingent upon our social environment, focuses on the individual's relations to others, and emphasises the importance of participation and inclusion. The CRPD thus acknowledges that the development of the human person is relational. ${ }^{55}$ In other words, the CRPD sees human beings as interdependent.

As relational theorists point out, the way you develop as a human being and the way you view yourself are intimately connected to your interaction with other persons and the various influences of the society you live in. In the words of Taylor 'the free individual of the West is only what he is by virtue of the whole society and civilisation which brought him to be and which nourishes him' ${ }^{56}$ We become who we are in community with other persons, and depend on others to function and navigate in society. Most of us might not even be able to survive on our own. Skills such as communicating or mastering a language cannot be acquired

\footnotetext{
${ }^{54}$ Peter Coleridge, 'Disability, Liberation and Development' (Oxfam 1993); MDAC, 'Legal Capacity in Europe. A Call to Action to Governments and to the EU' (2013); UNICEF, 'Summary Report. Violence against Disabled Children' (Thematic Group on Violence against Disabled Children 2005).

${ }^{55}$ Lord and Stein (n 29).

56 Taylor (n 5) 206.
} 
in isolation. ${ }^{57}$ Throughout our lives we depend on a wide range of social support functions (for example, friends, schools, hospitals) to live our lives and to develop our full potential as human beings.

The concept of interdependency breaks down the independent (able-bodied) vs. dependent (disabled) dichotomy, and instead positions individuals as more or less dependent on others in various aspects of life and in various periods of life. ${ }^{58}$ Hence, not only human rights, but also human beings are indivisible, interdependent, and interrelated. ${ }^{59}$

However, major theorists who invoke the notion of interdependency have not explained how persons with intellectual disabilities also are interdependent and not merely dependent. Arneil does not mention persons with intellectual disabilities specifically, ${ }^{60}$ and Kittay describes persons with severe intellectual disabilities as 'entirely dependent. ${ }^{61}$

To theories who explain that we have equal rights because we are more or less equally cooperating members in society, the notion of persons with intellectual disabilities as entirely dependent becomes especially problematic. ${ }^{62}$ However, as will be explained further in Section 4.4, the starting point of human rights conventions is the inherent dignity and worth-and hence the human rights - of all human beings. That the worth (and thus rights) are inherent, as opposed to qualified, means that the value and dignity of human beings are not related to "potential contributions" in any meaning of the term. Rather than being means to something else, human beings are ends in themselves. ${ }^{63}$

Ability to contribute should thus not be confused with human rights entitlement. Such a perspective ties human beings' value to their instrumental functioning for some other purpose. To see other individuals primarily as, for example, economic contributors or only as persons that one can cooperate with to promote one's own personal interest is to see other individuals as means. Hence, although we can value persons' positive contributions to society,

\footnotetext{
${ }^{57}$ Amitai Etzioni, The New Golden Rule: Community and Morality in a Democratic Society (Basic Books 1998).

${ }^{58}$ Arneil (n 1); Mégret (n 2), 'The Disabilities Convention: Human Rights of Persons with Disabilities or Disability Rights?'; Mégret (n 2), 'The Disabilities Convention: Towards a Holistic Concept of Rights.'

${ }^{59}$ The indivisibility, interdependency and interrelatedness of human rights is underlined in the Vienna Declaration and Programme of Action (12 July 1993) UNGA Res 48/121.

${ }^{60}$ Arneil (n 1).

${ }^{61}$ Kittay (n 50). Kittay does argue that persons with severe intellectual disabilities provide value and purpose for their caregivers. In itself, however, this is not an argument for why such persons interact with others and are valuable in themselves.

${ }^{62}$ Wasserman and others (n 7).

${ }^{63}$ Immanuel Kant, The Metaphysics of Morals (Cambridge University Press 1797); Stein (n 2); Jack Donnelly, Universal Human Rights in Theory and Practice (3th edn, Cornell University Press 2013); Mary Ann Glendon, 'Knowing the Universal Declaration of Human Rights' (1998) 73 Notre Dame Law Review 1153; Timothy P Shriver, Fully Alive: Discovering what Matters Most (Macmillan 2014).
} 
we should not qualify their worth as human beings by using such measures. Our value should not be reduced to skills, capabilities or contributions, because it transcends such notions altogether.

In the context of human rights, our interdependency lies at a more fundamental level. Our social bonds and web of networks towards others constitute our own being. Because we are individuals belonging to, being shaped by, and relating to the greater community of humans we are indefinite subjects. ${ }^{64}$

Valuing all human beings as ends in themselves broadens our perspective in a way that makes us see that each of us contributes to the greater community by virtue of our individuality and particular talents. ${ }^{65}$

Although not relevant for human rights entitlement, it is wrong to presume that persons with intellectual disabilities cannot contribute to society. CRPD Article 8(2)(iii) states that States Parties should promote the 'recognition of the skills, merits and abilities of persons with disabilities, and of their contributions to the workplace and the labour market'. Persons are typically seen as non-contributors and thus as burdens if they cannot contribute economically to society. ${ }^{66}$ Some persons with intellectual disabilities can contribute economically, others cannot. The same is true for persons without intellectual disabilities. However, while economic contributions are important and useful, the economic perspective is a narrow perspective on what contributing means. There are many other ways of contributing.

Family members and others who closely interact with persons with intellectual disabilities can develop an increased agency for caring, tolerance and moral connections towards others, given the right circumstances. ${ }^{67}$ This should encourage decision makers to create the circumstances that facilitate for such enrichment. All individuals and relations between individuals are different and some will therefore have negative experiences in their interactions with someone who has an intellectual disability, as will be the case in other interactions, and a person with an intellectual disability will necessarily not have the same impact on different individuals. However, literature shows that those with close relationships

\footnotetext{
${ }^{64}$ Martin Buber, I and Thou (trans W Kaufmann) (1971).

${ }^{65}$ Stein (n 2).

${ }^{66}$ Oliver and Barnes (n 6).

${ }^{67}$ Tim Stainton and Hilde Besser, 'The Positive Impact of Children with an Intellectual Disability on the Family' (1998) 23 Journal of Intellectual and Developmental Disability 57; Richard P Hastings, Alexandra Beck and Christopher Hill, 'Positive Contributions Made by Children with an Intellectual Disability in the Family Mothers' and Fathers' Perceptions' (2005) 9 Journal of Intellectual Disabilities 155; Jan Blacher, Bruce L Baker and William E MacLean Jr, 'Positive Impact of Intellectual Disability on Families' (2007) 112 American Journal on Mental Retardation 330.
} 
to persons with intellectual disabilities can experience a strengthened knowledge of the value of close relations, the simple joys in life, the inherent dignity of all human beings, and the astonishing potential all individuals have when given a fair chance. ${ }^{68}$

By respecting and including persons with intellectual disabilities (as well as other marginalised people), the whole society can benefit from a huge untapped potential source of knowledge and insight. Focusing on the rights and living conditions of minority groups can lead to stronger human rights protection for all, because certain features of the human experience are more visible among discriminated groups. ${ }^{69}$ For example, acquiring knowledge on disability can be a way of understanding more deeply the vulnerability of the human condition. ${ }^{70}$

Disability rights can for example strengthen the rights of women by asserting the necessity of holistically addressing both negative and positive duties to achieve equality (for example, prohibiting exclusion as well as creating enabling social environments). ${ }^{71}$ A focus on giving each individual an opportunity to develop his or her agency can also strengthen the rights of the poor. Disability laws on reasonable accommodation in workplaces can be an eye-opener for the necessity of accommodating individuals with and without disabilities in ways that make them perform optimally. ${ }^{72}$ Additionally, disability rights can strengthen the rights of sexual minorities by making clear that 'atypical persons' are of no less worth. ${ }^{73}$

Moreover, a recognition of the potentially demanding caring relations between parents and children with intellectual disabilities can be used to promote political justice for caregivers in general. ${ }^{74}$ Focusing on the rights and living conditions of minority groups can lead to stronger protection of human rights for those who are related to persons with disabilities, because they are affected by the discrimination as well. ${ }^{75}$

\footnotetext{
${ }^{68}$ Michael Bérubé, 'Equality, Freedom, and/or Justice for All: a Response to Martha Nussbaum' in Eva Feder Kittay and Licia Carlson (eds), Cognitive Disability and its Challenge to Moral Philosophy (Blackwell Publishing Ltd and Metaphilosophy LLC 2010); Shriver (n 63); Eva Feder Kittay, Love's Labor: Essays on Women, Equality and Dependency (Routledge 1999); Feder Kittay (n 50).

${ }^{69}$ Shriver (n 63); Kimberle Crenshaw, 'Mapping the Margins: Intersectionality, Identity Politics, and Violence against Women of Color' (1991) 43 Stanford Law Review 1241; Kimberle Crenshaw, 'Demarginalizing the Intersection of Race and Sex: a Black Feminist Critique of Antidiscrimination Doctrine, Feminist Theory and Antiracist Politics' (1989) The University of Chicago Legal Forum 139.

${ }^{70}$ Fineman (n 52).

${ }^{71}$ Stein (n 2).

${ }^{72}$ Ruth O'Brien, Bodies in Revolt: Gender Disability and a Workplace Ethic of Care (Routledge 2013).

${ }^{73}$ Stein (n 2).

74 Eva Feder Kittay, 'Dependency, Equality, and Welfare' (1998) 24 Feminist Studies 32; Eva Feder Kittay, 'Welfare, Dependency, and a Public Ethic of Care' (1998) 25 Social Justice 123.

${ }^{75}$ For example, even in the most developed countries, parents of children with disabilities have their personal liberty strained because of the inadequacy of support given to persons with disabilities. This strained liberty ranges from not having the ability to travel abroad to not being able to work full time because of the obligations
} 


\subsection{RIGHTS ARE ACHIEVED THROUGH SUPPORTIVE RELATIONS}

A classic individualistic liberal ideal is that of being independent in the sense of not relying on others. ${ }^{76}$ The CRPD does not adhere to this ideal. The principle of '[f]ull and effective participation and inclusion in society' (Article 3) provides guidance concerning how the rights contained in the CRPD are to become a reality. It reflects the idea that individual rights are fully achieved only through social relations. In addition, inclusion in society is a goal in itself.

The CRPD's approach to make human rights a reality should be understood in accordance with its understanding of human beings as interdependent. The recognition of interdependency is a forceful one: our ability to thrive in the world and to make the best of ourselves depend on our interactions with others. This conceptualisation reorients what protecting human rights entails in a way that departs from the individualistic liberal ideal. Human rights cannot merely be protective shells around the individual; they also make demands on the social relations that bind us together and make us who we are. No one can meet the individualistic liberal ideal of being independent in the sense of not relying on others. Instead, we all depend on others to enjoy individual rights. Fulfillment of human rights, therefore requires not only avoidance of harm (negative obligations) and actions that provide or facilitate rights (positive obligations), but also inclusion of individuals in meaningful social relations. In fact, the different types of rights and obligations can all be understood more broadly as ways of regulating social relations so as to create societies where all individuals can fully enjoy their human rights (see Section 4.4).

The insight that rights are achieved through social relations helps us understand how the legal capacity (autonomy) — in practice understood as an individual's self-determination — can be realised for all persons with disabilities. Article 12 declares that States Parties have to make sure that persons with disabilities receive the help they need to make their own choices. Hence, as is common in the theoretical rights literature, autonomy is understood as self-governance, meaning the right to make one's own choices and control one's own life. ${ }^{77}$ However, the CRPD is novel in the sense that it sees autonomy as being enabled through the help of others.

one feels to secure a good life for one's child. Kittay (n 68) Love's labor: Essays on Women, Equality and Dependency.

${ }^{76}$ Nussbaum (n 1).

77 John Christman, 'Autonomy in Moral and Political Philosophy ' (2015) Stanford Encyclopedia

$<$ https://plato.stanford.edu/entries/autonomy-moral/> accessed 5 July 2017. 
As acknowledged by relational theory, everyone relies on decision-making support. For example, few of us examine political parties' platforms in detail, so we rely on help from others to decide who to vote for. We might watch the news, collect advice from friends, or read commentary Articles by professionals we trust. In Lord and Stein's words, we cede 'a measure of decisional power to others on whom we rely to investigate and express preferences' ${ }^{78}$ It is impossible to make good decisions without support from others, because an individual simply does not have the capacity to independently gather sufficient information on all issues. The right to vote is also covered in a separate provision of the CRPD: Article 29 on the right to participation in political and public life. This Article includes a duty for the State Parties to, where necessary, allow for voluntary assistance in voting as a means of 'guaranteeing the free expression of the will of persons with disabilities as electors' (Article 29(a)(iii)).

Assistance to persons with more extensive decision-making difficulties varies in extent and implementation, but not in nature. ${ }^{79}$ Persons with intellectual disabilities may, for example, need assistance with communication, provision of information in understandable formats, and inclusion in networks where they can draw on advice from trusted peers ${ }^{80}$ If a person cannot express preferences or manage personal finances, someone has to make decisions that reflect the interests of this person. In such cases, it is important that those who provide support have a good and personal relation to the person they are helping with decision making. It is also important that accountability mechanisms exist to prevent abuse. ${ }^{81}$

Full realisation of the right to self-determination also requires protection of other human rights. For example, participation (Articles 29 and 30) and inclusion in the community (Article 19) are important means by which a person's identity and personality, and hence preferences, are formed. The right to education (Article 24), freedom of expression, and access to information (Article 21) strengthen our capacities to make good decisions.

Yet, persons with intellectual disabilities are often excluded from society. In the more extreme cases, they are placed and kept in institutions. ${ }^{82}$ But even when living in a community,

\footnotetext{
${ }^{78}$ Lord and Stein (n 29) 45.

${ }^{79}$ Silvers and Francis (n 17).

${ }^{80}$ UN Committee on the Rights of Persons with Disabilities (n 36).

${ }^{81}$ Finding the best way to ensure the right to self-determination for persons with intellectual disabilities is necessarily a difficult task currently receiving much scholarly attention, see Anna Arstein-Kerslake, 'Restoring Voice to People: Realizing the Equal Recognition Before the Law of People with Cognitive Disabilities' (Dissertation, National University of Ireland, 2014); Janos Fiala-Butora, 'Reconstructing Personhood: Legal Capacity of Persons with Disabilities' (Dissertation, Harvard Law School, 2015).

${ }^{82}$ MDAC (n 54).
} 
they are commonly being socially isolated. ${ }^{83}$ The result is that they do not have equal access to the social institutions that make individuals develop and thrive. In a vicious circle, they are viewed as incapable of participating in society, and are accordingly excluded from the social arrangements that could increase individuals' social capabilities in the first place.

Exclusion is not experienced only by persons with intellectual disabilities: In practice, many persons with disabilities are denied equal rights, for example because many buildings, including polling stations, cultural venues, schools, and workspaces remain inaccessible to them. The CRPD urges States Parties to change this situation. It sees unfavorable social structures as impeding equal rights and emphasises the need for widespread changes in all aspects of society. On this point, it parallels feminist theory, which points out how white (nondisabled) men's powerful position in society is not a result of biological differences or hard work, but rather of the many social structures that favor these persons. ${ }^{84}$

Importantly, the purpose of social embeddedness is not only to maximise individuals' capabilities or to fulfill other rights. The rights to participation and to inclusion in the community are important rights in themselves. Article 19, for example, recognises 'the equal rights of all persons with disabilities to live in the community' and to 'choose their place of residence'. Article 26 states that habilitation and rehabilitation services are to '[s] upport participation and inclusion in the community and all aspects of society'. States Parties shall 'ensure an inclusive education system at all levels' (Article 24(1)), and make sure that education facilitates that persons with disabilities have full and equal participation as members of the community (Article 24(3)).

Hence, the purpose of the right to education is not only to strengthen individuals' capacities, but also to ensure that all individuals participate in something that is valuable in itself. In the words of Stein et al.,

inclusion is not only a structural issue about how we organize or change different aspects of the school - with reference to personnel, pedagogical methods, materials, and cultural structures - to fit the diversity of the students but also an ethical concept

\footnotetext{
${ }^{83}$ Suzanne Abbott and Roy McConkey, 'The Barriers to Social Inclusion as Perceived by People with Intellectual Disabilities' (2006) 10 Journal of Intellectual Disabilities 275.

${ }^{84}$ See for example Anita Silvers 'Feminist Perspectives on Disability' (2016) Stanford Encyclopedia $<$ https://plato.stanford.edu/archives/win2016/entries/feminism-disability/> accessed 6 May 2017, for an overview of feminist perspectives on disability.
} 
because it is for the purpose of something. In other words, inclusion is for participating in something that is valuable. ${ }^{85}$

Evidently, not all types of social relations or social embeddedness are conducive to human rights. Individuals become easy targets for abuse in situations ranging from personal medical care to consumer decisions, not only if they do not have a social network, but also if they are oppressed by persons in that network. ${ }^{86}$ Social relations are just if they observe each individual's human rights. To ensure human rights we must therefore look into how social structures can be oppressive and change them so that they support the human rights and freedom of all.

In sum, through its clear emphasis on the importance of the interconnection between the individual and the community, the CRPD sees the community and social relations not only as being important in realising individual rights, but also as valuable in themselves. 'The right to live in the world' entails more than to exist in it. ${ }^{87}$ It entails that one also has the right to participate in it. Our relations towards others are the source of self-perceptions, meaning, and human well-being. It is in relation to others that dignity and respect can emerge, and that individuals can fully develop their potential.

\subsection{HUMAN RIGHTS ARE IDEALS THAT INFORM HOW WE SHOULD TREAT EACH OTHER}

Political theorists commonly argue that some persons with disabilities do not have autonomy, and that they accordingly do not have human rights on an equal basis with others. ${ }^{88}$ Even though theorists may agree that social support strengthens the protection of rights and autonomy, and that just social relations are valuable in themselves, they may still insist that certain individuals cannot have equal human rights. No matter how much some individuals are accommodated, they will still not be able to perform "normal" tasks by themselves. Griffin, for example, acknowledges that autonomy is a developmental process, and claims that children achieve this quality when they grow older. ${ }^{89}$ Yet, he insists that because persons with intellectual disabilities lack autonomy they do not have human rights.

\footnotetext{
${ }^{85}$ Michael Ashley Stein, Charlotte McClain-Nhlapo and Janet E Lord, 'Education and HIV/AIDS. Disability Rights and Inclusive Development' in Malcolm Langford, Andy Sumner and Alicia Ely Yamin (eds), Millenium Development Goals and Human Rights (Cambridge 2013) 282.

${ }^{86}$ Lord and Stein (n 29).

${ }^{87}$ Jacobus ten Broek, 'The Right to Live in the World: the Disabled in the Law of Torts' (1966) 54 California Law Review 841.

${ }^{88}$ Nussbaum (n 1); Kittay and Carlson (n 1); Arneil (n 1).

${ }^{89}$ Griffin (n 12).
} 
The discrepancy between the CRPD, which seeks to protect the autonomy and human rights of all persons with disabilities, and the political theories of rights, which claim that some human beings do not have human rights on an equal basis with others, largely occurs because of different starting points. As mentioned in Section 4.2, the starting point for human rights conventions is that all human beings have human rights, and that they accordingly ought to be treated with the same dignity and respect. Human rights conventions thus seek to say something about what treating someone with dignity and respect entails regarding specific rights and obligations. In other words, they focus on how we can make sure that equal human rights become a reality. Theories arguing that we have human rights because of certain capabilitiessuch as autonomy - explicitly or implicitly question why we have human rights. In other words, these theories do not share the human rights conventions' starting point of human rights as rights that are possessed by virtue of being human, and they are discordant with how human rights are usually defined by those working to put them into practice. ${ }^{90}$

That all human beings should be treated with the same dignity and respect is an axiom that cannot be proven scientifically, because it is fundamentally a moral premise, which one may agree or disagree with. Any theory seeking to justify why we have human rights is likely to come up with some kind of qualification criterion (such as autonomy, rationality, empathy or vulnerability). By doing so, the theory is likely to exclude some human beings or at least implicitly evaluate them according to how far they are from fulfilling the criterion. Such a theory may in fact exclude all human beings at certain times in their lives. The same human beings may, for example, have human rights only when they are adults, but not if they are in a coma or acquire a disability.

The CRPD's statement on the autonomy of all persons with disabilities becomes hard to understand if read as an empirical claim (as the meeting of a qualification criterion). The same applies to the Universal Declaration's statement that all persons are born free and equal.

\footnotetext{
${ }^{90}$ To illustrate, consider another controversial right in the context of (severe) intellectual disability, namely the right to vote. Martha Nussbaum 'The Capabilities of People with Cognitive Disabilities' (2009) 40 Metaphilosophy 331 argues for proxy voting for those who currently cannot be accommodated in the electoral process. Janos Fiala-Butora, Michael A Stein and Janet E Lord, 'The Democratic Life of the Union: Toward Equal Voting Participation for Europeans with Disabilities' (2014) 55 Harvard International Law Journal 71 oppose this suggestion by giving examples of how proxy voting is likely to subordinate the voting-incapable. Nussbaum and Fiala-Butora et al agree that all persons with disabilities have a right to vote that is equal to that of their non-disabled peers, but they differ in their approach to what this entails in practice. Thus, even though one agrees to the premise of equal rights entitlement, the question of how to fulfill rights remains an open question. The discussion on how to fulfill rights is, however, of a different nature than discussions on why and whether a certain group of people has human rights. Only the former aligns with the human rights conventions' starting point of human rights as rights that we have by virtue of being human.
} 
There are indeed persons born into slavery or into an unjust class-based society and, depending on how we define autonomy, some may currently not have any autonomy at all. Instead, to make sense of such claims, human rights should be understood as ideals that inform how we should treat each other. As per the CRPD, we treat individuals as autonomous if we respect, protect, and fulfill their right to live and to lead their own lives, and the CRPD (particularly Article 12) gives an idea of how this can be done in practice.

By focusing on the process or act of just treatment, human rights theories can include all individuals on equal terms. Indeed, we can acknowledge that human beings differ widely in their abilities and characteristics, and yet perceive them as equal in the sense that they all have an equal right to be treated with dignity and respect. In other words, we are equal in the sense that we have equal human rights. This approach creates symmetry between different individuals. $^{91}$

Human rights are means that can help individuals flourish. Supportive relations strengthen individuals' capabilities. Because an individual is supported or obstructed by the way others relate to him or her, that is, by the way society is organised, the way we treat each other decides whether and how individuals can build, achieve, and use their capabilities. By denying someone human rights, we also deny the individual important sources for flourishing and development. It is not the case that everyone can do the same things if they are treated equally. However, importantly, the purpose of human rights is not to foster individuals' capabilities so that they reach the same external standard. The goal is rather to treat everyone according to the same moral standards (human rights) that make individuals develop and thrive, so that they can become the best versions of themselves.

The CRPD reflects this understanding by stating, for example in Article 24, that the right to education is to be directed to ' $[\mathrm{t}]$ he development by persons with disabilities of their personality, talents and creativity, as well as their mental and physical abilities, to their fullest potential' (emphasis added). The appropriate yardstick for success is thus not the extent to which individuals reach certain levels of capacities (this will of course be subject to large individual variations), but the extent to which we continuously do our best to treat each other with dignity and respect in an attempt to create societies where everyone can thrive according to their own abilities and needs.

\footnotetext{
${ }^{91}$ Hans Skjervheim, 'Deltakar og Tilskodar [Participant and Observer]' in Deltakar og Tilskodar og Andre Essays (Tanum-Norli AS 1976).
} 
Because different human beings have different abilities and challenges, equal rights enjoyment requires different approaches for different groups. The right to health, for example, applies to all human beings; however, to become a reality for all it must entail that those who give birth receive proper pre-natal care. In other words, pre-natal care is specific to a certain group of people, but it is part of ensuring the equal right to health for all. In the same manner, supported decision making is a way of achieving the equal human right to self-determination for one specific group. The CRPD tells us something about how human rights are to become a reality for persons with disabilities, persons who face challenges that differ from the challenges faced by those who do not have a disability. Ensuring that persons with intellectual disabilities (and others) have equal human rights thus means finding ways to make sure that they are treated according to the same ideals governing the treatment of others. The CRPD brings us closer to this goal.

\section{CONCLUSION}

Political theories of rights addressing disability commonly portray persons with disabilities as "deviant" and dependent, and persons with intellectual disabilities in particular are seen as lacking the autonomy required to have human rights. In contrast, the CRPD acknowledges the human rights of all persons with disabilities. It states that persons with disabilities are a natural part of human diversity and that all persons with disabilities have autonomy and the same rights as their non-disabled peers. Drawing on relational theory, this Article has given a theoretical basis for such statements, and it has been argued that addressing human rights in the context of intellectual disability also theoretically strengthens the human rights of all human beings.

It has been argued that disability is a natural part of humanity. All humans can acquire a disability at any time. If disability is seen as vulnerability and a stronger dependency on others because of cognitive or physical capacities differing from those of the "average person," then all persons will experience disability during their lives, particularly in childhood and in old age. Persons with intellectual disabilities differ from the "average person" in cognitive capacity, but cognitive capacity also varies across persons without disabilities. Moreover, it is just one part of a person's personality and does not predefine an individual. Disability is a part of humanity that has previously not been sufficiently addressed by human rights law and theory. 
Rather than dividing individuals into those who are independent and those who are dependent, all human beings are better perceived as interdependent. Our social bonds and networks constitute our own being, and a disability perspective on rights makes particularly visible that we all depend on others to develop and thrive. Hence, human beings are indivisible, interdependent, and interrelated.

Further, it has been argued that rights are achieved through supportive relations, and that achieving such relations is in itself an important purpose of human rights. For example, just embeddedness in social relations is crucial for the realisation of individuals' right to selfdetermination (autonomy). This is true also for persons with intellectual disabilities, although the necessary assistance required to fulfill this right for such individuals may vary in extent and implementation.

However, to understand fully the CRPD's assertions on the autonomy and equal rights of all human beings, it is important to move away from an understanding of human rights as justified by equal individual capabilities to an understanding of human rights as ideals that inform how we should treat each other. This point is well demonstrated within the context of intellectual disability. Human beings differ widely in their abilities and characteristics, but a fundamental moral premise of human rights conventions is that human beings are equal in the sense that they have equal human rights. Focusing on the process or act of just treatment allows us to include all individuals on equal terms.

The Article adds both to the literature on human rights conventions and to the literature on human rights theory. By combining the two, it contributes to making sense of the CRPD, which is important for its implementation, and to making human rights theory a good source of protection for all human beings. 